\title{
Selected Toxic Heavy Metals Levels in Vegetables, Soil and Irrigation Water at Awashriver, Ginchi Town, West Shoa Zone, Ethiopia
}

\author{
Getachew Ejigu ${ }^{1} \quad$ Bayissa Leta $^{2} \quad$ Alemayehu Abebaw ${ }^{2}$ \\ 1.Department of Chemistry, College of Natural and Computation Science, Bule Hora University, Bule Hora, \\ Ethiopia \\ 2.Departments of Chemistry, College of Natural and Computation Science, Ambo University, Ambo, Ethiopia
}

\begin{abstract}
The levels of selected heavy metals $(\mathrm{Cr}, \mathrm{Cd}$ and $\mathrm{Pb})$ have been determined in cabbage, onion, soil and Awash river used for irrigation have been investigated. The cabbage, onion, soil and Awash River water samples were collected from the farmlands around Ginchi Town of West Shoa Zone in which the Anmol Ethiopia PLC, a paper industry, were there. The samples were digested using properly optimized wet digestion procedures. The metal contents were analyzed using Flame Atomic Emission Spectroscopy (FAES). However, $\mathrm{Cd}$ and $\mathrm{Pb}$ were not detected in all samples. Likewise, the highest level in onion samples was, $\operatorname{Cr}(0.59 \mathrm{mg} / \mathrm{L})$. High concentrations of $\mathrm{Cr}(71.85 \mathrm{mg} / \mathrm{Kg})$ were detected in soil samples on which the Onion vegetable was gown, while the corresponding values of $\mathrm{Cr}$ detected in the Onion sample itself was $59.35 \mathrm{mg} / \mathrm{Kg}$. The levels of selected metals in downstream water (after effluent from Anmol Production Ethiopia PLC is mixed with Awash River) samples used for irrigation. It can be concluded that, $\mathrm{Cr}$ in both soil onion and onion exceeded the FAO limit of maximum recommended level vegetable plant, so that the consumption of this Onion might cause hazards with respective to $\mathrm{Cr}$ and hence care must be taken.
\end{abstract}

Key phrases: toxic heavy metals, soil, vegetables, irrigation water

DOI: $10.7176 / \mathrm{CMR} / 12-2-04$

Publication date: February $29^{\text {th }} 2020$

\section{INTRODUCTION}

Vegetables are rich sources of vitamins, minerals, and fibers and also have beneficial ant oxidative effects. However, the intake of heavy metal contaminated fruit and vegetables may pose a risk to human health; hence the heavy metal contamination in living organisms some metals such as $\mathrm{K}, \mathrm{Mg}, \mathrm{Ca}, \mathrm{Mn}, \mathrm{Fe}, \mathrm{Co}, \mathrm{Cu}$, and $\mathrm{Zn}$ which are very important for growth and health are known as essential metals, besides these there are metals like $\mathrm{Cd}$ and $\mathrm{Pb}$ which are undesirable and harmful for human health are known as non-essential elements (Daniel, 2007). However, if the levels of these metals are higher than the recommended limits, their role changes to a negative dimension. Human beings can be exposed to heavy metal ions through direct and indirect sources like food, drinking water, exposure to industrial activities and traffic Some heavy metals such as $\mathrm{Cr}, \mathrm{Cd}$, and Pd normally occurring in nature are not harmful to our environment because they are only present in very small amounts (Sanayei et al., 2009). On the other hand, environmental pollution has become major challenge causing contamination of agricultural soil, water and air which were then taken up by crop plants consumed by human. Therefore, the levels of various toxic organic and inorganic elements have generally increased; some of which were to the level harmful to man and other living things. Plants, which are intermediate reservoirs of these metals, may take these metals from soil, water and air and accumulate them in or in their tissues due to their several biochemical mechanisms developed during their evolution and course of life which enables them adapt and tolerate new or chemically imbalanced environment (Adeyeye, 2005).

Industrial wastewater contains high levels of heavy metals that may pollute the water once it is discharged to the nature. These metals include arsenic, chromium, copper, zinc, aluminum, cadmium, lead, iron, nickel, mercury, and silver. Heavy metals are elements that have more than five times the specific gravity than that of water. They are one of the most toxic types of water pollutants. At least 20 metals are considered to be toxic, and approximately half of these metals are emitted to the environment in quantities that are hazardous to the environment, in addition to the human health (Khaled et al., 2008).

Heavy metals are defined on the basis of three different criteria which include density, atomic number and their chemical properties (Siddiquee et al., 2015). Heavy metals can accumulate in the soil at toxic levels due to the long-term application of wastewater. The contamination of vegetables with metals due to soil and atmospheric contamination poses a threat to their quality and safety. Heavy metals are extremely persistent in the environment. They are non-biodegradable and non-thermo degradable and therefore readily accumulate to toxic levels (Akguc et al., 2008).

Heavy metals are one of a range of important types of contaminants that can be found on the surface and in the tissue of fresh vegetables. Heavy metals, such as cadmium, copper, lead, chromium and mercury, are important 
environmental pollutants, particularly in areas under irrigated with waste water (Bigdeli and Seilsepour, 2008). Dry-ashing and wet-digestion are the common method of soil, plant and water sample digestion for elemental analysis. Dry-ashing methods are comparatively simpler and safe than wet-digestion methods but may introduce error due to volatilization, especially for arsenic (As), selenium (Se), cadmium (Cd) and mercury (Hg) (Hoeing et $a l ., 1998)$. The use of physic-chemical properties of water to assess water quality gives a good impression of the status, productivity and sustainability of such water body (Mustapha, 2008. Hence this study was designed to create awareness about the level of pollutions in the selected study area by investigating the levels of selected heavy metals $(\mathrm{Pd}, \mathrm{Cr}$ and $\mathrm{Cd})$ in selected vegetable, soil and irrigation water sample collected from the specified area.

\section{Objectives}

\section{General Objective of this study was}

The general objective of this study was to determine toxic heavy metals $(\mathrm{Pb}, \mathrm{Cd}$ and $\mathrm{Cr})$ concentration in soil, water sample and selected vegetables grown in contaminated areas around Awash River irrigation farms land.

The specific objectives of the study were

To determine the total concentrations of toxic heavy metals $(\mathrm{Cd}, \mathrm{Pb}, \mathrm{Cr})$ in soils and irrigation water sample from Awash River.

To determine the concentration of $\mathrm{Cr}, \mathrm{Pb}, \mathrm{Cd}$ in vegetable crops (cabbage and onion) grown in contaminated area around this Awash area.

\section{MATERIALS AND METHODS}

\subsection{Description of the study area}

The study area was located between $8^{\circ} 43^{\prime} 04^{\prime \prime} \mathrm{N}-9^{\circ} 17^{\prime} 19^{\prime \prime} \mathrm{N}$ latitude and $37^{\circ} 47^{\prime} 39^{\prime \prime} \mathrm{E}-38^{\circ} 20^{\prime} 47^{\prime \prime} \mathrm{E}$ longitude of Dendi woreda (IFPRI, 2012). The relative location of this area is bounded by Jeldu and Ilfata woreda in the North, Ejersa lafo woreda in the East, Ilu woreda in the south-east, Dawo woreda in the south and Ambo in the West. Anmol Ethiopian product P.L.C. Company which produces paper is located South of Ginchi town. Historically, the name of the district 'Dendi' is derived from Lake Dendi. Today, Dendi is one of the twenty three woredas of West Shoa zonal administration in Oromia National Regional State .The total area of the woreda is 105,180 hectares (BOFED, 2007).

The woreda is sub-divided into 48 rural and 4 urban kebele administrations. Agro-ecologically it is divided into two agro-climatic zones of dega (21 percent) and woina-dega (71 percent). Distance of the woreda capital (Ginchi) from zonal capital (Ambo) is $35 \mathrm{kms}$ while the distance of woreda from the regional capital (Finfinne) is $77 \mathrm{kms}$.

\subsection{Chemicals, Reagents and Standard Solution}

All the chemicals used were analytical reagent grade. Deionized water was used for all sample preparations processes throughout the study. Sulphuric acid, $\mathrm{H}_{2} \mathrm{SO}_{4}(98 \%)$ and hydrogen peroxide, $\mathrm{H}_{2} \mathrm{O}_{2}(30 \%), \mathrm{HClO}_{4}(37 \%)$ and $\mathrm{HNO}_{3}(69-72 \%)$ were used for digestion. Working standard solutions of $1000 \mathrm{ppm}(\mathrm{Cr}, \mathrm{Cd}, \mathrm{Pb})$ were prepared from their respective salts. The $\mathrm{pH} 4$ and 7 buffer solutions were used for $\mathrm{pH}$ meter calibration.

\subsection{Apparatus and Equipment}

The instruments used for this study were FAAS Agilent Technology- 4100 for toxic heavy metal characterization of irrigation water, vegetable and soil samples. Common laboratory apparatuses included different sized beakers, Erlenmeyer flasks, funnels, graduated cylinders, volumetric flasks, block digester, fume hood, centrifuge, shaker, droppers, glass pipettes, burette, spatula, measuring cylinders, plastic knife, vinyl gloves, steel less steel auger, stirrer, mortar, pestle, polyethylene bags, analytical balance, conical flasks and oven were used in this study.

\subsection{Sample Collection and Preparation}

\subsubsection{Vegetable Sample Collection and Preparation}

About $1 \mathrm{Kg}$ of vegetable samples Cabbage (Brassica oleracea) and Onion, grown using irrigation water, were collected from systematically identified sample collection sites in the month of January, 2018.Each vegetable samples was collected manually using vinyl gloves for protecting hands (for both Cabbage and Onion) and made a composite sample after being carefully washed (with tap water and then with double distilled water to eliminate adsorbed dust and particulate matters), cut and chopped (using plastic knife) and thoroughly mixed to constitute representative sample. The collected samples then separately packed in polyethylene bags and transported to Ambo University laboratory for further treatment. In the laboratory, collected plant samples were thoroughly washed and further cut and chopped into smaller pieces using plastic knife in order to facilitate drying. The samples were then air-dried for five to six days and further dried in hot air oven at $50-60^{\circ} \mathrm{C}$ for $24 \mathrm{hrs}$, to remove moisture until it maintain constant mass following the procedure reported by Adugna (Adugna et al., 2015). The dried samples were ground into powder using acid washed commercial mortar and pestle and then sieved to $2 \mathrm{~mm}$ mesh size. 
The sieved samples were finally stored in polyethylene bags and kept in desiccators until the time of digestion.

\subsubsection{Soil Sampling and Preparation}

Soil samples (about $1 \mathrm{Kg}$ ) were collected from 0-20 cm depth from the site were respective vegetable samples were collected (for each vegetable sample) with an auger following the procedure reported by (Poggio et al., 2008) and made a composite sample. Then the samples were placed in clean polyethylene bags and transported to the Ambo university laboratory for pretreatment and analysis. Larger soil particles and other debris were removed from the soil samples and then air dried in a dry and dust free place at room temperature $\left(2{ }^{\circ} \mathrm{C}\right)$ for 5 days, followed by oven drying to constant weights. The samples were then ground with a mortar and pestle to pass through a $2 \mathrm{~mm}$ sieve and homogenized. The dried, sieved and homogenized soil samples were placed in polyethylene bags until the time of digestion.

\subsubsection{Water Sampling}

Water samples from Awash River being used for irrigation purpose were collected from two different sites. One sample (represented as N1) was collected from downstream of the River after the effluent from Anmol product Ethiopian P. L.C. is mixed with the River and the second sample (represented as N2) was collected from upstream of the River, from about 100 meter above before mixing point of effluent from Anmol product Ethiopian P.L.C with the Awash River. Water samples were collected in properly cleaned and dry polyethylene bottles. Samples were taken where the water was visibly flowing and well mixed. The collected water samples were immediately acidified with $1 \mathrm{~mL}$ nitric acid and transported to Ambo University laboratory using Ice Box for later use for analysis of metal concentrations. The purpose of the acid is to keep the metals in solution and to avoid adsorption to the container walls (APHA, 1999).

\subsection{Digestion of Soil, Water sample and Vegetable Samples}

The water sample from each sampling bottle was mixed thoroughly by shaking. A $50 \mathrm{~mL}$ aliquot of water sample was pipetted into a digestion flask. The metal percentage found in water was estimated by digestion of the water sample using $5 \mathrm{~mL}$ concentrated $\mathrm{HNO}_{3}$ and $3 \mathrm{~mL} \mathrm{H} \mathrm{H}_{2}$ at a temperature below $180{ }^{\circ} \mathrm{C}$ for two hour until a clear solution was observed. The clear solution was then diluted to $50 \mathrm{~mL}$ using volumetric flask. Blank digestion was also carried out following the same procedure (Sanayei et al., 2009). Blank solution containing all reagents with $50 \mathrm{~mL}$ of distilled water except water sample. All samples were digested in triplicate. The digest was analyzed for concentrations of toxic heavy metals and essential metals by using FAAS and/or FAES.

To $0.5 \mathrm{~g}$ of homogenized powdered vegetable sample $5.5 \mathrm{~mL}\left(\mathrm{HNO}_{3}-\mathrm{HClO}_{4}-\mathrm{H}_{2} \mathrm{O}_{2}\right)(3: 2: 0.5, \mathrm{v} / \mathrm{v} / \mathrm{v})$ were added in digestion flask. The mixture was heated at $240{ }^{\circ} \mathrm{C}$ over $3 \mathrm{~h}$ on block digester. After digestion completed, the clear and colorless solution was transferred to a $50 \mathrm{~mL}$ volumetric flask. Each digestion tube was rinsed with distilled water to collect any possible residue, and added to the volumetric flask and then made up to the volume with distilled water. Then dilute samples were stored in $50 \mathrm{~mL}$ plastic bottles (high density polyethylene) until analysis. Each vegetable sample was digested and analyzed in triplicate to confirm precision of the result. The blank solution was prepared by taking a mixture of $0.5 \mathrm{~g}$ of lithium carbonate, $3 \mathrm{~mL} \mathrm{HNO}_{3}, 2 \mathrm{~mL} \mathrm{HCLO}_{4}$ and 0.5 $\mathrm{mL} \mathrm{H}_{2} \mathrm{O}_{2}$ and was treated similarly as that of the sample (Tadele et al., 2015). The toxic heavy metals and essential metals were analyzed by FAAS and/or FAES.

The $0.5 \mathrm{~g}$ dried and homogenized soil sample was transferred in to $50 \mathrm{~mL}$ digestion flask in triplicate. In process of the digestion of these samples, a mixture $\mathrm{HNO}_{3}(69 \%-72 \%), 37 \% \mathrm{HClO}_{4}$ and $\mathrm{H}_{2} \mathrm{O}_{2}$ with volume ratio of 2:3:0.5 was added to each digestion flask and the digestion process was carried out in digestion hood (at $\left.270^{\circ} \mathrm{C}\right)$ for three hours. Finally, the mixture was filtered with Whatman No. 42 filter paper to the $50 \mathrm{~mL}$ volumetric flask then diluted to the mark with deionized water following the reported standard procedure (Hizkeal, 2012; Kedir, 2015). The filtrate was analyzed for the total content of toxic heavy metals and essential metals by FAAS or FAES. The blank reagent was prepared by taking $0.5 \mathrm{~g}$ of Sucrose and digested following the same procedure used for soil sample digestion and determination the concentrations of essential metals were determine also using by FAAS or FAES.

\subsection{Method Validation}

\subsubsection{Spiking of Experiment}

Method validation is the process of providing analytical method that is acceptable for its anticipated purpose. In present study due to the absence of certified reference materials for soil, vegetable and irrigation water samples in our laboratory, the validity of the digestion procedure, precision and accuracy of FAAS and FAES was assured by spiking soil, vegetable and irrigation samples with standard of known concentration.

The spiked and non-spiked vegetables, soil, and water samples were digested following the same procedure employed in the digestion of the respective samples and analyzed in similar condition. Then the percentage recovery of the analyzed was calculated by Eq. 1(Deribachew et al., 2015; Kedir, 2015).

$\%$ Recovery $=\left(\frac{\text { CM in the spik samples }- \text { CM in the non spik sample }}{\text { Amount added }}\right) \times 100$ 
Where, $\mathrm{CM}=$ concentration of metal of interest

\subsubsection{Method Detection Limit and Instrument Detection Limit}

Three replicate blank samples were digested following the same procedures utilized for digesting the soil, vegetable and irrigation water samples. Each blank was assayed for its metal contents $(\mathrm{Cr}, \mathrm{Cd}, \mathrm{Pb})$ by FAES. The SD of the three replicate blanks was calculated to determine the Method Detection Limit(MDL) and Instrument Detection Limit(IDL) was calculated as three times the standard deviations using Eq. 2 (David and Terry, 2008, Meseret et al., 2013).

$$
(\mathrm{MDL}=\mathrm{yB} \pm 3 \mathrm{SD})
$$

Where; $\mathrm{yB}=$ mean of the replicate blanks

$\mathrm{SD}=$ Standard deviation of the blank

\subsection{Calibration and spiking standard preparation}

All working standard solution was prepared by diluting stock standard solutions (1000) of the metals to be analyzed. The calibration standard solution was used to calibrate the instrument response with respect to analyze concentration (USEPA,2001).In this work a series of six standard solution which were lying within the working linear range of the instruments were prepared by serial dilution of the stock standard solution in to $50 \mathrm{~mL}$ volumetric flasks.

For the spiking processes of the irrigation water, vegetables and soil samples, a mixture of standard solution containing $100 \mathrm{mg} / \mathrm{L}$ of Ca,75 mg/L of Mg,50 mg/L for Zn, $125 \mathrm{mg} / \mathrm{L}$ of each Na and K $18.5 \mathrm{mg} / \mathrm{L}$ of Cr and 25 $\mathrm{mg} / \mathrm{L}$ of each $\mathrm{Pb}$ and $\mathrm{Cd}$ were prepared. This mixture of standard solution was obtained by taking $10 \mathrm{~mL}$ of Ca, $7.5 \mathrm{~mL}$ of $\mathrm{Mg}, 12 \mathrm{~mL}$ for each $\mathrm{Na}, \mathrm{K}$, and $5 \mathrm{~mL}$ of $\mathrm{Zn}, 1.9 \mathrm{~mL}$ of $\mathrm{Cr}$ and $2.5 \mathrm{~mL}$ of each $\mathrm{Pb}$ and $\mathrm{Cd}$ stock standard solution $(1000 \mathrm{mg} / \mathrm{L})$ in to $50 \mathrm{~mL}$ volumetric flask and diluting to the mark with distilled water.

\subsection{Toxic Heavy Metals}

Concentrations of $\mathrm{Pb}, \mathrm{Cd}, \mathrm{Cr}$ in the extracted soil, irrigation water and vegetables samples were estimated by using FAAS Agilent Technology- 4100. The instrument was calibrated using 1000ppm standard solution of respective heavy metals as well as blanks. Calibration curves for each toxic heavy metals were set to ensure the accuracy of the instrument and to confirm that the results of determination were true and reliable. Standard stock solutions of $1000 \mathrm{ppm}$ for all the metals were prepared. These solutions were diluted for desired concentrations to calibrate the instrument (A multi-element solution containing $\mathrm{Cd}, \mathrm{Cr}, \mathrm{Pb}, 1000 \mathrm{ppm}$ was utilized to prepare elemental calibration solutions. This multi-element solution was prepared using the extraction solution and digestion solution.

\subsection{Statistical Analysis}

The analysis of variance ANOVA was performed to examine the significance level of all parameters measured. Least Significant Difference (LSD) test was used for means comparison. The level of significance for the F-test and means comparison might be $\mathrm{p}<0.05$. Methodological precision was therefore evaluated with percentage relative standard deviation (\%RSD), which was calculated using Eq. 9

$\% \mathrm{RSD}=\left(\frac{S}{\bar{X}}\right) \times 1009$

Where: $\mathrm{S}=$ Standard deviation $\bar{x}=$ Mean value

\section{RESULTS AND DISCUSSION}

\subsection{Optimization of digestion procedures for metal analysis}

From the optimization procedure, the digestion of $0.5 \mathrm{~g}$ of both each vegetable (cabbage and onion) with mixtures of $3 \mathrm{~mL} \mathrm{HNO}_{3}, 2 \mathrm{~mL} \mathrm{HClO}_{4} \& 0.5 \mathrm{mLH}_{2} \mathrm{O}_{2}$ digested at a temperature of $240^{\circ} \mathrm{C}$ for 3 hours until it gave clear solution. These optimum digestions were selected based on clarity of digestion solution, minimum reagent consumption, minimum digestion time \& minimum temperature applied for complete digestion of the samples. After digestion, the samples were cooled \& diluted to $50 \mathrm{~mL}$ and analyzed by FAAS.

A $0.5 \mathrm{~g}$ of each soil sample was weighted \& digested with a mixture of $2 \mathrm{~mL} \mathrm{HNO}_{3}, 3 \mathrm{~mL} \mathrm{HClO}_{4}$ and $0.5 \mathrm{~mL}$ $\mathrm{H}_{2} \mathrm{O}_{2}$ at a temperature of $270^{\circ} \mathrm{C}$ for 3 hours to obtain a clear solution. These optimum conditions were selected based on clarity of digest, minimum reagent consumption, Minimum digestion time and minimum temperature applied for complete digestion of the samples. After optimum conditions were established, the samples were digested, cooled and diluted to $50 \mathrm{~mL}$ volumetric flask and assayed for metal content by using FAAS. 
Table 1. Optimization parameter of cabbage, onion and soil samples digestion procedure for metal

\begin{tabular}{|c|c|c|c|c|c|c|c|}
\hline \multirow{2}{*}{ NO } & \multicolumn{4}{|c|}{ Reagent volume } & \multirow{2}{*}{$\begin{array}{c}\text { Maximum } \\
\text { Temp. }\end{array}$} & \multirow{2}{*}{ Time(min) } & \multirow{2}{*}{ Results } \\
\hline & $\mathrm{HNO}_{3}$ & $\mathrm{HClO}_{4}$ & $\mathrm{H}_{2} \mathrm{O}_{2}$ & Total & & & \\
\hline 1 & 2 & 2 & 1 & 5 & 270 & 120 & Yellow \\
\hline 2 & 2 & 2 & 0.5 & 4.5 & 270 & 160 & Clear solution \\
\hline 3 & 3 & 2 & - & 5 & 240 & 150 & Almost clear \\
\hline 4 & 3 & 3 & - & 6 & 140 & 120 & Almost clear \\
\hline 5 & 5 & 2 & 0.5 & 7.5 & 240 & 120 & Yellow green \\
\hline 6 & 3 & 2 & 0.5 & 5.5 & 240 & 180 & Clear solution \\
\hline 7 & 5 & 2 & - & 7 & 210 & 160 & Light yellow \\
\hline 8 & 4 & 1 & - & 5 & 240 & 180 & Almost clear \\
\hline 9 & 2.5 & 2 & - & 5 & 240 & 120 & Light brown \\
\hline \multirow[t]{2}{*}{10} & 5 & 2 & - & 7 & 240 & 120 & Almost clear \\
\hline & & & & Onion & & & \\
\hline 1 & 2 & 2 & 1 & 5 & 180 & 120 & yellow solution \\
\hline 2 & 5 & - & 1 & 6 & 200 & 120 & brown solution \\
\hline 3 & 5 & 2 & - & 7 & 240 & 120 & Almost clear \\
\hline 4 & 3 & 3 & - & 6 & 180 & 180 & Almost clear \\
\hline 5 & 3 & 2 & 0.5 & 5.5 & 240 & 180 & Clear solution \\
\hline 6 & 2 & 2 & - & 4 & 210 & 150 & Yellow solution \\
\hline 7 & 2 & 2 & - & 4 & 210 & 150 & clear solution \\
\hline 8 & 2.8 & 2.5 & - & 5 & 210 & 190 & Light brown \\
\hline 9 & 2.8 & 2.5 & - & 5 & 250 & 150 & Clear solution \\
\hline \multirow[t]{2}{*}{10} & 6 & - & - & 6 & - & & Light yellow \\
\hline & & & & Soil & & & \\
\hline 1 & 8 & 2 & 1 & 11 & 180 & 120 & Yellow \\
\hline 2 & 5 & 3 & 1 & 9 & 240 & 270 & Clear Almost \\
\hline 3 & 6 & 1.5 & 0.5 & 8 & 240 & 270 & Almost clear \\
\hline 4 & 5 & 1 & - & 6 & 120 & 120 & Light brown \\
\hline 5 & 3 & 1 & - & 4 & 240 & 270 & Clear solution \\
\hline 6 & 2 & 3 & 0.5 & 5.5 & 270 & 180 & Clear solution \\
\hline 7 & 4 & 1 & 0.5 & 5.5 & 240 & 180 & Almost Clear \\
\hline 8 & 4 & 1 & - & 5 & 240 & 170 & light yellow \\
\hline 9 & 3 & 3 & 1 & 7 & 180 & 170 & Light yellow \\
\hline 10 & 2 & 3 & 0.5 & 5.5 & 240 & 170 & Clear solution \\
\hline 11 & 5 & 3 & - & 7 & 240 & 270 & Light yellow \\
\hline
\end{tabular}

\subsection{Elemental Analysis of samples}

After proper calibration of the instruments, the samples were aspirated into the FAAS or FAES instrument according to standard method (APHA, 1999). Concentrations of $\mathrm{Cd}, \mathrm{Cr}$ and $\mathrm{Pb}$ were assayed by using FAAS Agilent Technology (Model-AT-4100) at Holeta Agricultural and Research Center, Natural Resource Management, Soil Laboratory. The digested of irrigation water, vegetable and soil samples were analyzed for $\mathrm{Cr}$, $\mathrm{Pb}$, and $\mathrm{Cd}$ by air acetylene FAAS(Ata.et.al,2013).

The Intermediate standard solution of the metals was prepared from their respective $1000 \mathrm{mg} / \mathrm{L}$ stock solution using their respective salts by dilution method. Parameters such as burner, lamp alignment, slit width and wave length were optimized for maximum signal intensity of instrument by running three replicate measurements of blank samples for each vegetable, soil \& irrigation water samples.

Concentration $(\mathrm{mg} / \mathrm{L})=\frac{\left(\text { Concentration }\left(\frac{\mathrm{mg}}{\mathrm{L}}\right)-\text { Blank }\right) \mathrm{XV}}{\mathrm{M}}$

Where, $\mathrm{V}=$ Final volume $(50)$ of solution after digestion, $\mathrm{M}=$ Initial weight $(0.5 \mathrm{~g})$ the sample

Table 2. Instrument operating condition for the analysis of metal in vegetable, soil \& irrigation water sample using FAAS.

\begin{tabular}{ccccccccc}
\hline Elements & $\mathbf{N a}$ & $\mathbf{K}$ & $\mathbf{C a}$ & $\mathbf{M g}$ & $\mathbf{Z n}$ & $\mathbf{C r}$ & $\mathbf{P b}$ & $\mathbf{C d}$ \\
\hline $\begin{array}{c}\text { Wave } \\
\text { length(nm) }\end{array}$ & 589.0 & 769.0 & 422.7 & 285.2 & 213.9 & 357.9 & 217.0 & 228.8 \\
Slit Width(nm) & 0.2 & 0.7 & 0.7 & 0.7 & 1.0 & 0.2 & 0.5 & 0.50 \\
Energy & - & - & 3.710 & 3.71 & 3.017 & 3.586 & 3.475 & 3.094 \\
IDL(mg/L) & 0.02 & 0.01 & 0.005 & 0.003 & 0.001 & 0.006 & 0.010 & 0.002 \\
Flame gas & Air/ $/ \mathrm{C}_{4} \mathrm{H}_{10}$ & $\mathrm{Air} / \mathrm{C}_{4} \mathrm{H}_{10}$ & Acetylene & Acetylene & Acetylene & Acetylene & Acetylene & Acetylene \\
\hline
\end{tabular}


Table 3. Instrument and Method Detection limits (IDL and MDL)

Instrument and method detection limits were determined as per the procedure indicated in methodology section of this paper and the data obtained was presented in Table 3.

\begin{tabular}{lcccc}
\hline Element & $\begin{array}{c}\text { IDL in } \\
\mathbf{m g} / \mathbf{L}\end{array}$ & $\begin{array}{c}\text { MDL of irrigation water } \\
\text { samples in } \mathbf{~ m g / L}\end{array}$ & $\begin{array}{c}\text { MDL of soil } \\
\text { samples in } \mathbf{~ m g / L}\end{array}$ & $\begin{array}{c}\text { MDL of plant } \\
\text { samples in } \mathbf{~ m g / L ~}\end{array}$ \\
\hline $\mathbf{C r}$ & 0.006 & 0.007 & 0.009 & 0.008 \\
$\mathbf{P b}$ & 0.010 & 0.016 & 0.044 & 0.011 \\
$\mathbf{C d}$ & 0.002 & 0.003 & 0.005 & 0.003 \\
\hline
\end{tabular}

\subsection{Determination of Calibration Curves}

\subsubsection{Instrumental Calibration}

Calibration curves were prepared to determine the concentration of the heavy metals in the sample solutions. According to the instrument operation manual to attain its better sensitivity, the working standards were then aspirated one after the other into the flame atomic absorption spectrometer and its absorbance was recorded. Calibration curves were plotted with six points for each metal standard solution using absorbance against concentrations $(\mathrm{mg} / \mathrm{L})$. Figure 1, is a sample calibration curve for $\mathrm{Cr}$ metal standard solutions. As can be witnessed from Table 4, the Correlation coefficient $\left(\mathrm{R}^{2}\right)$ values obtained are ranged from 0.997 to 0.999 which are very closer to the absolute value of 1 indicating that there is a strong relationship between the variables being correlated.

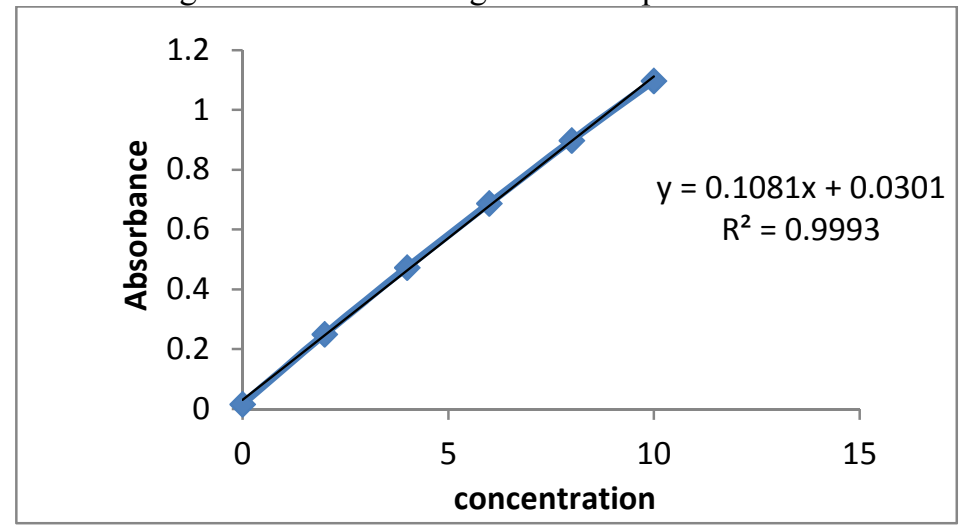

Figure 1. Calibration curve for $\mathrm{Cr}$ standard concentrations

Table 4. Concentration of Calibration standards used with correlation coefficients

\begin{tabular}{ccc}
\hline Element & Working standard $\mathbf{~ m g} / \mathbf{L}$ & Correlation coefficient $\left(\mathbf{R}^{\mathbf{2}}\right)$ \\
\hline $\mathbf{C d}$ & $0,0.5,1,1.5,2,2.5$ & 0.998 \\
$\mathbf{C r}$ & $0,2,4,6,8,10$ & 0.999 \\
$\mathbf{P b}$ & $0,0.5,1,1.5,2,2.5$ & 0.999 \\
\hline
\end{tabular}

\subsubsection{Recovery of the experimental procedures}

The recovery of experimental procedure for the determination of metals has been studded by spiking known concentration standard solution of each metal of interest and the percent recovery was calculated. The calculated percentage recovery data of the metals analyzed is presented in tables from Tables 5 indicating that a good percentage recovery of ranging 88.0 to $109.66 \%$ were obtained.

Table 5. Percentage recovery of spiked metal concentrations in soil, cabbage and water sample

\begin{tabular}{|c|c|c|c|c|c|}
\hline MetalMetal & $\begin{array}{l}\text { Concentration } \\
\text { before spiking } \\
(\mathrm{M} \pm \text { SDs) in ppm }\end{array}$ & $\%$ RSD & $\begin{array}{c}\text { Concentration after } \\
\text { spiking }(M \pm S D s) \text { in } \\
\text { ppm }\end{array}$ & $\begin{array}{c}\text { Amount } \\
\text { added (ppm) }\end{array}$ & \%Recovery \\
\hline \multicolumn{6}{|c|}{ Soil } \\
\hline $\mathrm{Cr}$ & ND & - & - & 0.75 & - \\
\hline Cd & ND & - & - & 1.00 & - \\
\hline $\mathbf{P b}$ & ND & - & - & 1.00 & - \\
\hline
\end{tabular}

\section{ND: not detected}

\subsection{Level of Selected Heavy Metals in Soil, Vegetables and Irrigation water Samples}

The concentrations of $\mathrm{Cr}, \mathrm{Cd}$ and $\mathrm{Pb}$ in the digested samples of soil, vegetable and irrigation water were determined by FAAS. The concentrations of these metals are reported as mean \pm standard deviation for triplicate measurement $(\mathrm{n}=3)$. As shown in Table 6,the analyzed metal in irrigation water $\mathrm{Pb}, \mathrm{Cr}$ and $\mathrm{Cd}$ were below the detection limits. The concentrations of, $\mathrm{Cr}, \mathrm{Cd}$ and $\mathrm{Pb}$, in sample of vegetables that cultivated around Ginchi Anmol production P.L.C irrigation farm land were presented in Table 6 .From the study almost the metals were accumulated to greater 
or lesser extents in the vegetable samples. The concentrations of toxic heavy metals in two the vegetable samples were higher than the FAO/WHO guideline values of $0.6 \mathrm{mg} / \mathrm{kg} \mathrm{Cr}, 0.1 \mathrm{mg} / \mathrm{kg} \mathrm{Pb} ; 0.02 \mathrm{mg} / \mathrm{kg} \mathrm{Cd}$. This might be as a results high accumulation $\mathrm{Cr}$ metals by plant from trace metals.

Table 6. Concentration of metals analyzed in soil, water and vegetable samples analyzed (mean $\pm \mathrm{Sd}$ )

\begin{tabular}{|c|c|c|c|c|c|c|}
\hline \multirow{3}{*}{$\begin{array}{c}\text { Metals } \\
\text { analyzed }\end{array}$} & \multicolumn{6}{|c|}{ Concentration of metals } \\
\cline { 2 - 7 } & Soil Samples (mg/Kg) & Vegetable samples (mg/Kg) & Water samples (mg/L) \\
\hline Cr & SO & SC & Onion & Cabbage & N1 & N2 \\
Cd & $71.85 \pm 2.47$ & ND & $59.35 \pm 52.4$ & ND & ND & ND \\
Pb & ND & ND & ND & ND & ND & ND \\
\hline
\end{tabular}

WhereND=Not Detected

$\mathrm{SO}$ - soil on which onion was grown

$\mathrm{SC}$ - soil on which cabbage was grow

N1=Awash River water sample after mixed with effluent from Anmol Product EthiopiaPLC (downstream)

N2= Awash River water sample before mixed with effluent from Anmol Product Ethiopia PLC (upstream

Table 7. Permissible level of metals in Soil samples, Vegetable sample and Water sample

\begin{tabular}{|c|c|c|c|c|c|}
\hline \multirow[b]{3}{*}{$\begin{array}{c}\text { Metals } \\
\text { analyzed }\end{array}$} & \multicolumn{5}{|c|}{ Concentration of metals (mg/Kg) } \\
\hline & \multicolumn{2}{|c|}{ Soil Samples } & \multirow{2}{*}{$\begin{array}{c}\text { Vegetable samples } \\
\text { Safe limit for plant } \\
\text { WHO(1996) }\end{array}$} & \multicolumn{2}{|c|}{ Water samples } \\
\hline & RMLFAO/WHO & EPA(2003) & & $\begin{array}{l}\text { WHO Safe } \\
\operatorname{limit}(\mathrm{mg} / \mathrm{Kg})\end{array}$ & $\begin{array}{c}\mathrm{EPA}(2003) \\
(\mathrm{mg} / \mathrm{L})\end{array}$ \\
\hline $\mathrm{Cr}$ & 50 & 20 & 0.06 & 0.10 & 0.05 \\
\hline Cd & 3 & 0.5 & 0.02 & 0.01 & 0.005 \\
\hline $\mathbf{P b}$ & 100 & 40 & 2 & 0.05 & 0.05 \\
\hline
\end{tabular}

$\mathrm{RML}=$ recommended maximum limit, Sources of RML values: (FAO/WHO, 2001; Lente et al., 2014), NM=Not Mention

Chromium (Cr): It plays a vital role in the metabolism of cholesterol, fat, and glucose. Its deficiency causes hyperglycemia, elevated body fat, and decreased sperm count, while at high concentration it is toxic and carcinogenic (Chishti et al., 2011). The $\mathrm{Cr}$ value in the soil onion samples were found $71.8 \mathrm{mg} / \mathrm{Kg}$. The highest contents of Cr occurred in the soils of onion and not detected in soil cabbage. WHO/FAO permissible limit of lead in soil is $50 \mathrm{mg} / \mathrm{Kg}$ (Lente et al., 2014). So, the concentration of chromium found onion soil as chromium (VI) was toxics and known human carcinogens samples around Anmol production Ethiopian P.L.C. irrigation farm might be harmful for human health.

In this study the chromium content of samples were analyzed from onion $59.35 \mathrm{mg} / \mathrm{Kg}$ and not detected in soil cabbage. The chromium contents of onion around Ginchi Anmol production Ethiopian P.L.C irrigation farm exceed maximum limit of metal concentration set by $(\mathrm{FAO} / \mathrm{WHO}, 2001)$ in onion vegetable studied .In line to these results Edema et al. (2009) stated that the highest concentration of chromium was found in onion of vegetables. In this study the of $\mathrm{Cr}$ content in onion vegetable was very high than save limit plant (WHO, 2006). The concentration of $\mathrm{Cr}$ in onion samples around Ginchi Anmol production Ethiopian P.L.C irrigation might be harmful for human health. The high concentration of $\mathrm{Cr}$ in the vegetables might be due to the application of untreated industrial effluent. By the continuous application of untreated industrial effluent builds up the concentration of metals into the soil. From the soil metals transfer to the plants and accumulate in the tissues of plants.

Lead $(\mathbf{P b})$ : It is a non-essential heavy metal. Pb causes oxidative stress and contributes to the pathogenesis of lead poisoning by disrupting the delicate antioxidant balance of the mammalian cells. High level accumulation of $\mathrm{Pb}$ in body causes anemia, colic, headache, brain damage, and central nervous system disorder (Rehman et al., 2013). Both the soil sample were not detected $\mathrm{Pb}$ WHO/FAO permissible limit of lead in soil is $100 \mathrm{mg} / \mathrm{Kg}$ (Lente et al., 2014). So, the concentration of lead not found two soil samples around Ginchi Awash irrigation farm not harm full by lead for human health.

The maximum $\mathrm{Pb}$ limit for human health has been established for edible parts of crops in China is $0.2 \mathrm{mg} / \mathrm{Kg}$ but this limit by WHO standards is $0.3 \mathrm{mg} / \mathrm{Kg}$. Data showed that not detected in both sample. Lead is a toxic element that can be harmful to plants, although plants usually show ability to accumulate large amounts of lead without visible changes in their appearance or yield. In many plants, $\mathrm{Pb}$ accumulation can exceed several hundred times the threshold of maximum level permissible for human. The introduction of $\mathrm{Pb}$ into the food chain may affect human health and thus, studies concerning $\mathrm{Pb}$ accumulation in vegetables have increasing importance. On the whole, both vegetables that were studied in this study not contaminated by lead.

The concentration of $\mathrm{Pb}$ in Awash irrigation water sample was not detected in both water samples. Lead value were found in from 0- 500 meter interval of sampling stations to be higher than $0.05 \mathrm{mg} / 1$, recommended limit of $\mathrm{Pb}$ in irrigation water(WHO, 2008). This makes the water unsuitable for human consumption as $\mathrm{Pb}$ is known to 
be toxic even at low levels with resultant ill-health effects as chronic exposure has been linked to growth retardation in children. The concentration of lead in both water samples around Anmol production Ethiopian P.L.C irrigation farm not harmful for human health.

Cadmium (Cd): It is also a non-essential heavy metal. It is extremely toxic even at low concentration. It causes learning disabilities and hyperactivity in children. The experimental results showed that Cd concentration in both soil samples were not detected WHO/FAO permissible limit of cadmium in soil is $3 \mathrm{mg} / \mathrm{Kg}$ (Lenteet al., 2014). So, the concentration of cadmium were not found in both vegetables grown soil sample around Anmol production Ethiopian P.L.C. irrigation farm and not harmful by $\mathrm{Cd}$ for human health. as shown table 15 the irrigation water both upper stream and upper stream were not detected around Anmol production Ethiopian P.L.C.

The vegetable samples collected around Ginchi irrigation farm not contain the Cd concentration. The efficiency of plants to absorb metals can be evaluated by their ability of metal uptake or soil to plant transfer factors. Although soil concentrations may be the source of metals for plants uptake through roots by the process of translocation (Farooq et al. (2008) reported that $\mathrm{Pb}$ and $\mathrm{Cd}$ were above toxicity level in leafy vegetables grown in vicinity of an industrial area of Faisalabad, Pakistan, whereas other heavy metals (Cr) were within the permitted limits, but the concentration of $\mathrm{Cd}$ in both vegetable samples around Anmol production Ethiopian P.L.C. irrigation farm not be harmful for human health, since Cd concentration in the two vegetable samples were not detected as shown table 6 above.

\subsection{Analysis of variance (ANOVA)}

Student F-test was calculated to identify whether the means of the concentration between the cabbage and soil cabbage ,onion and soil onion and irrigation water samples vary significantly by Statistical Package for Social Science (SPSS statistic 20.0 Microsoft window) as well as excel work sheet (Microsoft Office Excel, 2010) was employed to draw some of the curves. Linear regression analysis of calibration curve was used to calculate unknown concentration, sensitivity, correlation coefficients and standard deviation. Average concentration and standard deviations of triplicate measurement for the sample were reported. Variance in sampling and analysis were determined by F-test through One-way ANOVA (Miller and Miller, 2005). However, the variations for Cr were not significant except vegetable sample $(\mathrm{p}>0.05)$ in the all samples, but $\mathrm{Cd}$ and $\mathrm{Pb}$ were not detected in all four samples, since, $\mathrm{Cr}$ was detected and not significance in soil onion and onion vegetables and all parameter were significance difference by using one way variance (ANOVA).

\subsection{Heavy metal Transfer Factor (TF) from soil to vegetables}

The transfer coefficient quantifies the relative deference in bioavailability of metals to plants and is a function of both soil and plant properties. The coefficient is calculated by dividing the concentration of a metal in a vegetable crop by the total metal concentration in the soil. In the present study, the TF of deferent heavy metal from soil to vegetable are presented in Table 20. The TF or PCF cabbage vegetable to soil value were 0.36 for $\mathrm{Cr}$ and nondetected for $\mathrm{Cr}, \mathrm{Pb}$ and the TF of Onion vegetable to soil value were 0.819 for $\mathrm{Cr}$ and not detected for $\mathrm{Cd}$ and $\mathrm{Pb}$.

Table8. Soil to vegetable transfer factor

\begin{tabular}{|c|c|c|c|}
\hline Vegetables & $\mathrm{Cr}$ & $\mathrm{Cd}$ & $\mathrm{Pd}$ \\
\hline Cabbage $(\mathrm{mg} / \mathrm{L})$ & $\mathrm{ND}$ & $\mathrm{ND}$ & ND \\
\hline Onions $(\mathrm{mg} / \mathrm{L})$ & 0.819 & $\mathrm{ND}$ & ND \\
\hline
\end{tabular}

\section{CONCLUSION AND RECOMMENDATION \\ 4.1. CONCLUSION}

The analyzed metal in irrigation water $\mathrm{Pb}, \mathrm{Cr}$ and $\mathrm{Cd}$ were not detected. The concentrations of $\mathrm{Cr}, \mathrm{Cd}$ and $\mathrm{Pb}$ in the digested samples were determined by FAAS or FAES. The concentrations of these metals are presented with their respective standard deviation. Lead and cadmium trace toxic metals were below method detection limit in all cabbage and onion vegetables, soil and Awash water samples used for irrigation. The high chromium level detected might be originated from wastewater indiscriminately released from the paper factory located in close proximity to Awash River.

The analyzed metal in vegetable sample $\mathrm{Pb}$ and $\mathrm{Cd}$ were below the detection limit while the other metal detected among macro elements and $\mathrm{Cr}$. However in the three sample $\mathrm{Cd}$ and $\mathrm{Pb}$ were not detected, but $\mathrm{Cr}$ was found in onion and soil onion and very toxic and harmful for human health while consumed edible part of onion and also caused chromium (VI) compounds are toxics and known human carcinogens. The trend of TF for toxic heavy metal in vegetable Onion and Cabbage samples.

\subsection{RECOMMENDATION}

Further studies are recommended in the study area of all samples including Cabbage, Onion, soil and water samples 
with respect to heavy metals including Arsenic, Mercury, manganese, Iron were not addressed in the present study. The accumulation of metals in plants is also a factor of the plant type, growth media, applied agrochemicals, season of cultivation, global pollution status and local pollution incidence. Therefore, further assessment in other parts of the country and including other metals and nonmetallic constituents are possible area.

Comprehensive study of relation between the soil, water and plant is the preferred optional method to trace the sources of the minerals that assessment of soil composition of the area was recommended particularly for the toxic chromium. Generally the high level of metals might be originated from wastewater indiscriminately released from the paper factory located in close proximity to Awash River and the soil, vegetables and Awash river water used for irrigation area contaminated with the effluent (wastewater) being released from Anmol production Ethiopian P.L.C. and it recommended that the waste water must be safe to discard to Awash river.

\section{Acknowledgments}

I would like to acknowledge Ambo University and Holeta Agricultural Research Center, Agricultural and Nutritional Research Laboratory for providing laboratory facilities to conduct the heavy metal analysis. Additionally, I would like appreciate my advisor Dr. Bayissa Leta and co-advisor Dr. Alemayehu Abebaw for their careful supervision, excellent guidance and encouragement from the very beginning of the proposal development up to the final thesis write up. I have a special respect and appreciation to them for their fatherly advice in all aspect and achievements of today's success.

\section{References}

Adeyeye, E. I. Distribution of Major elements (Na. K, Ca, Mg) in the various anatomical parts of Fadama crops in Ekiti state, Nigeria, Bulletin of Chemical Society of Ethiopia, (2005), 19(2), 175-183.

Adugna Boke, Negussie Megersa and Endale Teju. (2015). Quantitative Determination of the Heavy Metal Levels in the Wild Edible Plant Parts and their Corresponding Soilsthe Central and Western Regions of the Oromia State, Ethiopia. Journal of Environmental \& Analytical Toxicology, 5(5):299-307.

Akguc, N., Ozyigit, I.I. and Yarci, C. (2008). PyracanthacoccineaRoem.(Rosaceae) as a biomonitor for Cd, $\mathrm{Pb}$ and $\mathrm{Zn}$ in Mugla province (Turkey).Pakistan Journal of Botany, 40 (4): 1767-1776.

APHA (American Public Health Association). (1999). American water works association, Water environment federation. Standard methods of the examination of water and wastewater, $20^{\text {th }} \mathrm{ed}$. New York: American Public Health Association, APHA, AWWA, and WPCF.

Bigdeli, M. and Seilsepour, M. (2008). Investigation of Metals Accumulation in Some Vegetables Irrigated with Waste Water in Shahre Rey-Iran and Toxicological Implications. American-Eurasian Journal Agricultural \& Environmental Science, 4 (1): 86-92.

Chishti, K.A., Khan, F.A., Hassan, S.S.M.(2011). Estimation of heavy metals in the seeds of blue and whitecapitalism's of silybummarianum grown in various districts of Pakistan. Journal of Basic and Applied Science, 7(1): 45-49.

Daniel Woldegebriel,(2007),Levels of Essential and Non-Essential Metals in Commercially Available Ethiopian Black Teas. (Unpublished M.Sc. thesis), Addis Ababa University, Addis Ababa, Ethiopia.

David, A.A. and Terry, P.(2008). Limit of Blank, Limit of Detection and Limit of Quantitation. Clinical Biochemist Review, 29: 49-52.

DeribachewBekana., Made, M., NigussieDechassa and Taddesse, A.M. (2015). Selected heavy metals in some vegetables produced through wastewater irrigation and their toxicological implications in Eastern Ethiopia. African Journal of Food, Nutritional and Development, 15(3): 10013-10032.

Farooq, M., A. Farooq, R. Umer, (2008). Appraisal of heavy metal contents in different vegetables grown in the vicinity of an industrial area. Pakistan J. Sci., 40(5): 2099-2106.

Hizkeal Tsade, (2012). Determination of copper, zinc, cadmium, and lead concentrations in traffic density roadside soils in some selected town of east Ethiopia. MSc. Graduate project, Haramaya University, Haramaya, Ethiopia.

Hoeing, M., Baeten, H., Vanhentenrijk, S., Vassileva, E. and Quevauviller, P.H. (1998).Critical discussion on the need for an effective mineralization procedure for the analysis of plant material by atomic spectrometric methods.Analytica chimicaacta, 358: 85-94.

KedirHussien. (2015). Chemical fractionation of some trace heavy metals $(\mathrm{Cd}, \mathrm{Cr}, \mathrm{Cu}$ and $\mathrm{Pb})$ in some selected farm lands of Haramaya Woreda, Ethiopia. MSc. Graduate project, Haramaya University, Haramaya, Ethiopia.

Khaled, A., Ola Abdelwahab, O., El-Sikaily, A., El Nemr, A., (2008). Treatment of wastewater containing toxic chromium using new activated carbon developed from date palm seed. Journal of Hazardous Materials, 152: 263-275.

Lente, I., Ofosu-Anim, J., Brimah, A.K. andAtiemo, S. (2014).Meta Heavy metal pollution of vegetable of 
Vegetable crops irrigated with wastewater s Irrigated with Wastewater in Accra, Ghana.West African Journal of Applied Ecology, 22(1), 41-58.

Meseret Amde, NegussieMegersa, Abi M. Taddesse and Tesfa Bedassa. (2013). Determination of the levels of selected metals in seeds, flowers and fruits of medicinal plants used for tapeworm treatment in Ethiopia.Toxicological \& Environmental Chemistry, 95(1): 82-100.

Mustapha, K. M., (2008). Assessment of water quality of Oyun Reservoir, Offa, Nigeria, using selected physicchemical parameters. Turkish Journal of Fisheries and Aquatic Sciences, 8:309-319.

Poggio, M., Hepperle, E. and Marsan F.A. (2008). Metals pollutions and human bioaccessibility of topsoils in Grugliasco, Italy.Environmental Pollution, 157: 680-689.

Rehman, A., Ullah, H., Khan, R.U. and Ahmad, I. (2013). Populationbased study of heavy metals in medicinal plant Capparis decidua.International Journal of Pharmacy and Pharmaceutical Sciences, 5(1): 108-113.

Sanayei, Y., Ismail, N and Talebi, S.M., (2009). Determination of heavy metals in Zayandeh rood, Isfahan-Iran. World Applied Sciences Journal, 6(9):1209-1214.

Siddiquee, S., Rovina, K., Al Azad, S., Naher, L., Suryani, S. and Chaikaew, P.(2015). Heavy Metal Contaminants Removal from Wastewater Using the Potential Filamentous Fungi Biomass: A Review. Journal of Microbial \& Biochemical Technology, 7(6): 384-393.

Tadele Atinafu, Taddese Mekonnen, and Somasundaram, J. (2015). Determination of some toxic heavy metal accumulation in medicinal plants commonly used in Gondar area district, Northwestern Ethiopia.International Journal of Pharmacy and Analytical Research,4(4): 399-405.

WHO. (2006). WHO Guidelines for the Safe Use of Wastewater, Excreta and Greywater.Vol. I: Policy and Regulatory Aspects. Vol. II: Wastewater Use in Agriculture. Vol. III: Wastewater and Excreta Use in Aquaculture. Vol. IV: Excreta and Greywater Use in Agriculture. Geneva: World Health 